\title{
PECULIARITIES OF INCLUSIVE EDUCATION OF ASD CHILDREN IN UKRAINE
}

\author{
LARYSA RYBCHENKO \\ Faculty of Special Pedagogy and Psychology, \\ Dragomanov National Pedagogic University, 9 Turgenivska st., Kiev, Ukraine \\ E-mail address: rolla_r@mail.ru \\ IHOR OsTROVSKII \\ Faculty of Telecommunications, \\ Lviv Polytechnical National University, 12 Bandery st., Lviv, Ukraine \\ E-mail address: katerynaostrova@gmail.com
}

@) $\odot \Theta \Theta$

\begin{abstract}
Despite the fact that special education in Ukraine is quite extensive and eveloped, education itself and social psychological development remain unavailable for children with ASD. The article aim is to show a model of autistic children inclusion in the educational system of Ukraine taking into account the experience of success. The investigated group consists of 20 children with ASD and 20 children with mental retardation from a boarding school aged from 8 to 9 years. The children indices were investigated according to BinetSimon Scale for intelligence level determination, method of neuropsychological research according to Alexander Luria for psychophysical development level determination and Childhood Autism Rating Scale for autism level determination. The analysis of inclusive education implementation in the educational system of Ukraine has been conducted. The results of studies have shown that children with ASD have substantially lower indices of speech development, capacity for imitation as well as concentration of attention than children with mental retardation. Conductance of social intervention based of TEACCH therapy elements for group of children with ASD has shown their progress in indices of social interaction, emotional reaction and communication. The results obtained allow us to build a model of inclusion of children with ASD in the educational system of Ukraine. The main components of the model are considered.
\end{abstract}

Keywords: autism spectrum disorder (ASD), inclusive education, social services, psychological indices.

\section{INTRODUCTION}

According to the definition given in the psychiatry manual, autism is denoted as immersion in the world of personal experiences with weakened or lost contact and interest with reality, lack of willingness to communicate and poor emotional display (Snezhnevsky, 1985). According to the American autism association, autism is a disorder of neural development characterized by impaired social interaction 
and communication, and by restricted interests and repetitive behavior (Ornitz, 2013). Anna Freud interprets autism as psychological disturbance, extreme psychological alienation resulting in lost or sharply weakened contacts with the environment and immersion in the world of personal experiences (Freud, 1999). The term autism is also used in non-clinical sense to denote individual characteristics of a person who is more focused on his own inner feelings and whose thoughts are more dependent on affective tendencies (Meshcheryakova, \& Zinchenko, 2004). Russian scientists, Klara Lebedynska in particular, interpret autism as escape from reality, immersion in one's own world; no reactions to external influence or how paradoxical they are; inactivity and excessive vulnerability while contacting the peers (Lebedynska, \& Nicolska, 1991).

Students with ASD are given special attention in the educational process. In Ukraine special education is a system of differential training applied in both educational and innovative institutions such as rehabilitation, recreation, social educational, training rehabilitation and psychological medical educational centres. Legal documents certifying modernization of education in Ukraine towards integrated education through standardization based on multidisciplinary approach were adopted by the Ministry of Education during 2009-2013 years. Implementation of an integrated approach to teaching children with mental and physical developmental disorders in Ukraine is viewed by scientists in the context of prospects and opportunities for further special education development Vitaliy Bondar (Bondar, 2003), Kateryna Ostrovska (Ostrovska, 2012), Alla Kolupayeva (Kolupayeva, 2007), Tetyana Skrypnyk (Skrypnyk, 2008), Alexander Shulzhenko (Shulzhenko, \& Ostrovskii, 2014), Dina Shulzhenko (Shulzhenko, 2009), etc.

We analyzed statistical data obtained during 2010 - 2013 years from regional psychological medical educational advice offices and concluded: despite the fact that special education of Ukraine is quite extensive and developed, education itself and social psychological development remain unavailable for autistic children. Our analysis on implementation of integrated and inclusive education in the educational system of Ukraine has proved that in most regions pre-school and school began «spontaneous inclusion». Therefore, the following integrated education problems of primary importance are defined as:

- teachers lack psychological and professional qualification to work with children with special physical and mental developmental disorders;

- lack of required conditions and equipment for the children with special physical and mental developmental disorders, ASD included, to study in the inclusive groups;

- lack of special assistance in teaching (an assistant teacher, assistant to a child). The teacher himself is not able to pay sufficient attention to both healthy children and their peers with special educational requirements;

- intolerant attitude of healthy peers, their parents and others towards children with special physical and mental developmental disorders, etc. that makes such children and their parents feel quite uncomfortable under integrated teaching. 
A survey among pre-school and school teachers determined factors of unavailability for integrated teaching of children with special educational needs and their healthy peers as follows:

- lack of adapted environment, special equipment, technical conditions, etc.;

- lack of specialized professionals as well as special knowledge and teaching experience;

- insufficient educational and psychological qualification of teachers;

- lack of teaching and methodological support.

The excellent system of education of ASD students is developed in Europe countries, particularly in Poland they are provided with complex psycho-social educational support. The special education program for ASD students was adopted by Polish Ministry of Education since 1999. The development of the special program is connected with famous scientists such as Ewa Pisula (Pisula, 2003), Marzena Kowaluk (Kowaluk, 2009), Lucyna Bobkowich-Lewartowska (Bobkowich-Lewartowska, 2000), etc. Development of individual syllabus requires a team work that involves stages of working out tasks and syllabus contents, multidisciplinary student's capability diagnostics, syllabus modification according to the capability of the student (Peeters, 2003). The educational process is planned and coordinated by a team of teachers, psychologists and remedial teachers who make individual programmes of educational therapy that include:

- individual syllabus to work with a child with mental and physical disorders;

- requirements for arrangement of educational environment;

- selection of equipment and special-purpose training resources (didactic and methodological material, measuring instruments, necessary tools etc.).

Therefore, the aim of the article is to show a model of autistic children inclusion in educational system of Ukraine taking into account the successful Polish experience introduced in Lviv experimental school as well as Kiev and Lviv pre-schools. The experience will be widespread in all regions of Ukraine.

The proposed educational model operates in Lviv experimental boarding school "Trust" guided by NGO "Kolping's Family", Lviv state pre-school guided by Charitable Fund "Open Heart" and Kiev private pre-school guided by Foundation "Children with a future". The model is based on TEACCH programme represented by Eric Schopler (Schopler, \& Reichler, 1986).

The education of autistic children in experimental institutions includes a wide range of services such as diagnosis and assessment, individualized treatment programmes, special education, social skills training, parent training and counselling. The primary aim of the educational programme is to help prepare children to live or work effectively at home, at school and in the community. Special emphasis is placed on helping children with ASD and their families live together more effectively by reducing or removing 'autistic behaviours'.

The principles and concepts guiding the educational system have been summarized as:

- improved adaptation: through the two strategies of improving skills by means of education and of modifying the environment to accommodate deficits; 
- parent collaboration: parents work with professionals as co-therapists for their children so that techniques can be continued at home;

- assessment for individualized treatment: unique educational programmes are designed for all individuals on the basis of regular assessments of abilities;

- structured teaching: it has been found that children with ASD benefit more from a structured educational environment than from free approaches;

- skill enhancement: assessment identifies emerging skills and work then focuses upon these;

- cognitive and behaviour therapy: educational procedures are guided by theories of cognition and behaviour suggesting that difficult behaviour may result from underlying problems in perception and understanding;

- generalist training: professionals are trained as generalists who understand the whole child, and do not specialize as psychologists, speech therapists etc.

\section{METHODOLOGY}

According to the main principles of TEACCH, educational work also provides multidisciplinary training for professionals dealing with children with ASD and their families as well as maintaining an active research programme (Ostrovska, 2010). The partial results of the research are presented in the article.

In the psychological study 40 students of secondary schools were involved. These were 20 children with ASD from boarding school "Trust" aged from 8 to 9 years (10 girls and 10 boys) and 20 students with mental retardation of the same age group (9 girls and 11 boys) from state school "Dream". The following methods were used: Binet-Simon Scale for intelligence level determination; method of neuropsychological research according to Alexander Luria for psychophysical development level determination; and Childhood Autism Rating Scale (CARS) for autism level determination. Neuropsychological diagnosis allows us to differentiate learning and behavior difficulties caused by the individual characteristics of the functioning of the brain structures of exclusion related to improper influence or pedagogical features of child. This technique is not limited to detecting only weaknesses in child development, but defines the zone of proximal development, contributing to the construction of individual programs for remedial developmental education of the child (Luria, 1970). Scale tests of mental development by Alfred Binet and Theodore Simon involves the study of mental development of children. Childhood Autism Rating Scale consists of 15 items that can diagnose children with ASD, to distinguish them from children with disabilities, but without the syndrome of autism; makes it possible to distinguish the degree of autism. The obtained data were processed with use of correlation analysis as well as comparative analysis according to Student $t$-criteria.

The long-etudinal investigation includes three stages:

1) Preliminary studies of children indices in groups of children with ASD and mental retardation and their comparison. 
2) Conducting of social intervention aimed at social skills forming in a group of children with ASD. We have used the intervention based on TEACCH therapy elements for one group of 10 children (experimental group). The interventions lasted for 52 weeks 2-3 times a week with duration 45 minutes. The rest of children with ASD (10 children) serves as the reference group. They had no social intervention, but learned at the same conditions at school.

3) Making a comparison of CARS scale indices in experimental and reference groups of children with ASD.

\section{EXPERIMENTAL RESULTS AND THEIR DISCUSSION}

According to the results of the preliminary evaluation of ASD children by CARS method, $67.5 \%$ of them have a difficult and 32.5\% - moderate form of autism. Children with severe autism have low level of relationships with people, imitation, emotional response, adaptation to change, visual response, auditory response, verbal and non-verbal communication. The results of tests of mental development by A. Binet and T. Simon have shown that the average level of intellectual development in children with ASD is lower as compared to children with mental retardation (see Fig.1). Use of neuropsychological research by Alexander Luria allow us to establish in children with ASD prevailing low volume of hearing speech memory, predominant inhibition of auditory traces, low sustainability to auditory tracks, playback order of given auditory stimuli, low reproduction of sound structure of words, poor regulation and control of hearing speech memory, low level, regulation and control of visual memory.

Fig.1. Difference between level of intellectual development of children with ASD and mental retardation.

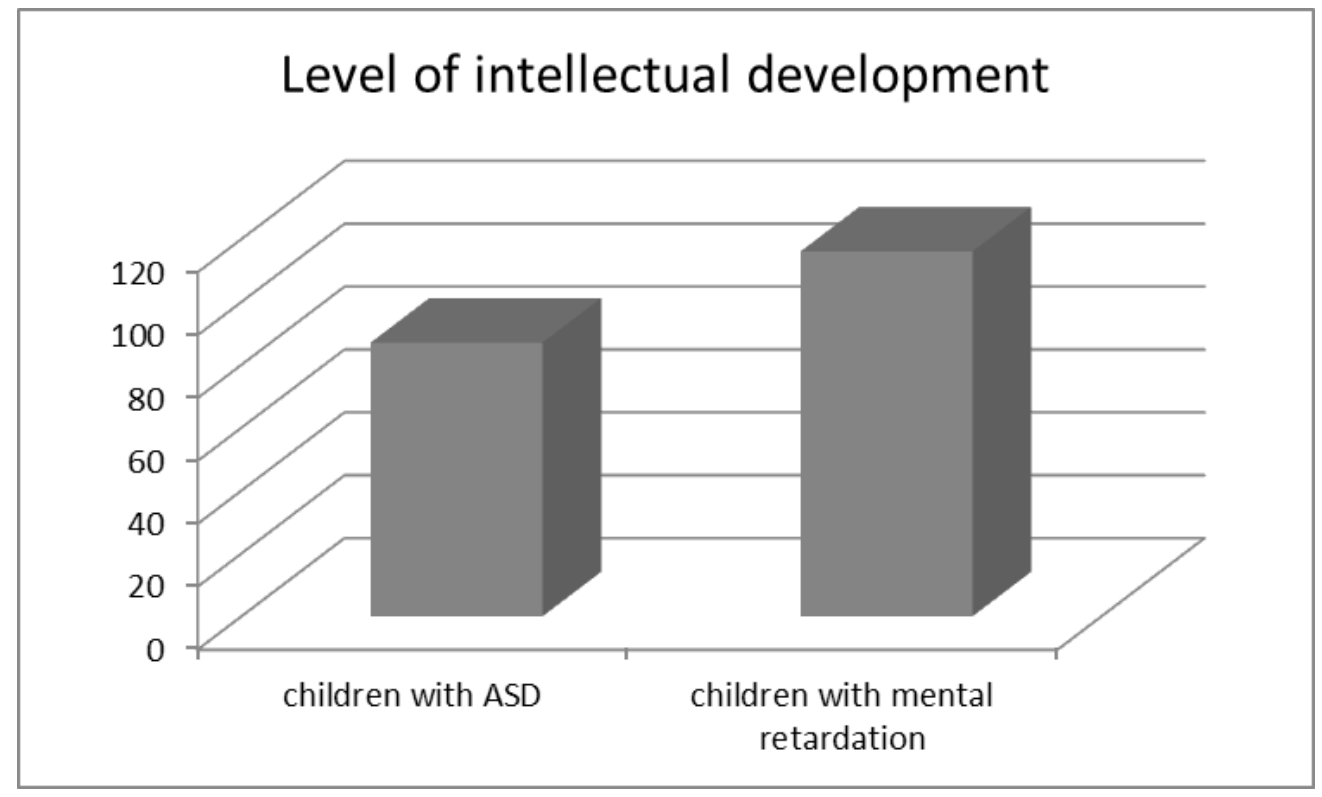

Source: Authors`research. 
According to the results of the correlation analysis in the group of children with ASD we found a direct correlation between indicators of verbal communication and relationships with others $(r=0,46)$ (see Fig.2). Ability of a child to make contact with others, ease of communication is directly connected with developed verbal communication. We also established a direct correlation between indicators of sensitive reactions and relationships with others $(r=0,26)$ (see Fig.2). Lack of communication difficulties associated with sensory reactions, in which the child comes into contact with others, adequately responds to tactile interaction.

Fig. 2. Correlation coefficients between the indices of ASD children.

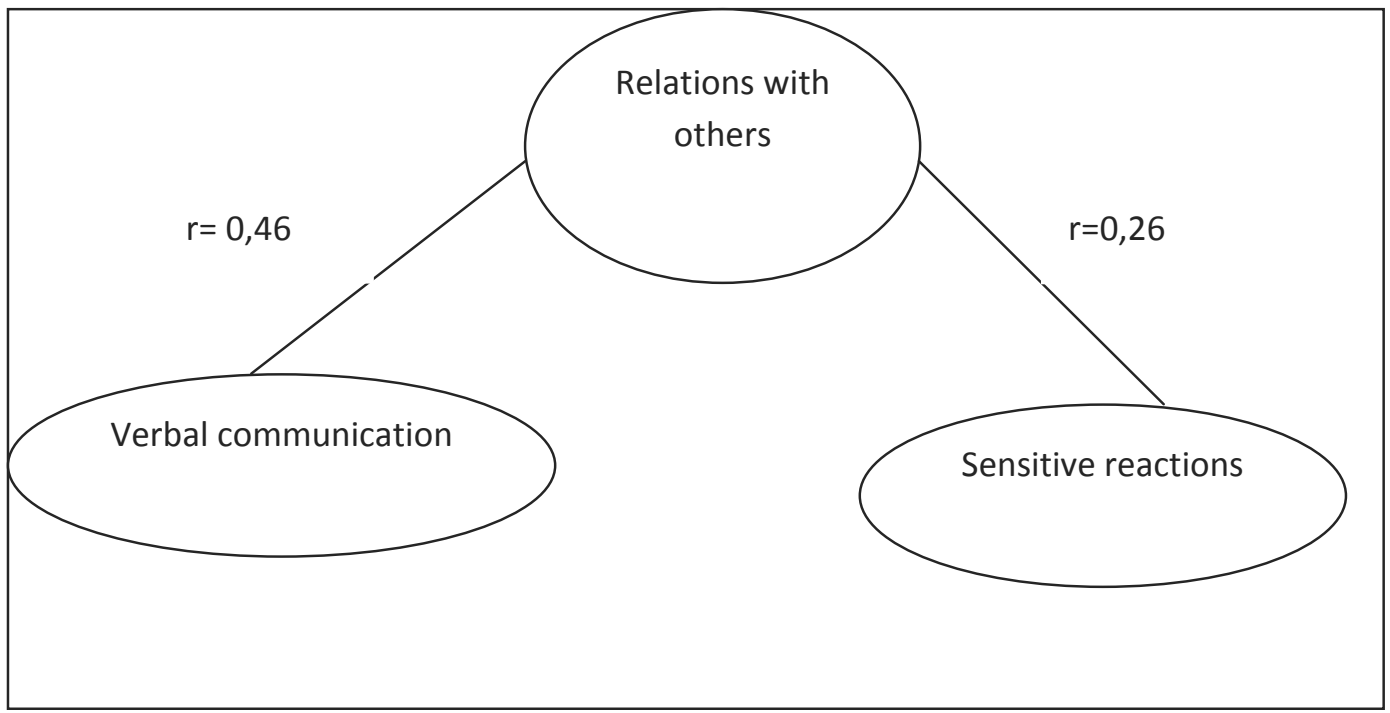

Source: Authors`research.

A direct correlation between indicators of mental development and imitation $(r=0,48)$ was found. A high level of mental development of a child is associated with the ability to simulate a role at playing game. This kid works better with a therapist.

Through a comparative analysis (by Student t-test) psychological characteristics of children with mental retardation and children with ASD at the level of $p$ $<0.05$ have shown such differences (see Table 1 ):

- difference in the level of speech $(t=2,740, d f=39$, with $p=0,0091)$. A group of children with ASD has lower level of language development as compered to children with developmental delays. This can be explained by the fact that children with ASD have certain features of the development. They avoid eye contact, preferring solitude, do not use sign language, and, thus their language development is delayed. In contrast, children with mental retardation often express verbal and nonverbal speech in interaction with adults and peers.

- difference in the level of capacity for imitation $(t=3,243, \mathrm{df}=39$, with $\mathrm{p}$ $=0,0045)$. A group of children with ASD as compared with children with mental retardation has lower ability to imitate. A child with ASD can simulate only simple behavior, sometimes imitates after promotion by adult or 
with delay. Instead, the child with mental retardation can imitate sounds, words, expressions, movements, can point by finger that she/he wants to participate in the games.

- difference in the level of concentration $(t=2,645$, $d f=39$, with $p=0,0116)$. A group of children with ASD as compared to children with mental retardation has lower concentration of attention. This can be explained by the fact that children with ASD are limited in opportunities to focus attention. In contrast, children with mental retardation have greater tendency to stability an attention.

Tab. 1. A comparison of parameters of children with ASD and mental retardation.

\begin{tabular}{|l|l|l|}
\hline Parameter & Children with ASD & Children with mental retardation \\
\hline Lever of speech development & 6,286 & 7,427 \\
\hline Level of capacity for imitation & 4,536 & 6,361 \\
\hline Level of concentration of attention & 3,248 & 4,572 \\
\hline
\end{tabular}

Source: Authors` research.

One can conclude that children with ASD have lower levels of imitation, speech development and concentration of attention than children with mental retardation. The fulfilled analysis confirms the main statement about the necessity of creation of special conditions for ASD children's education.

Fig. 3. Dynamics of changes in ASD children indices due to social intervention.

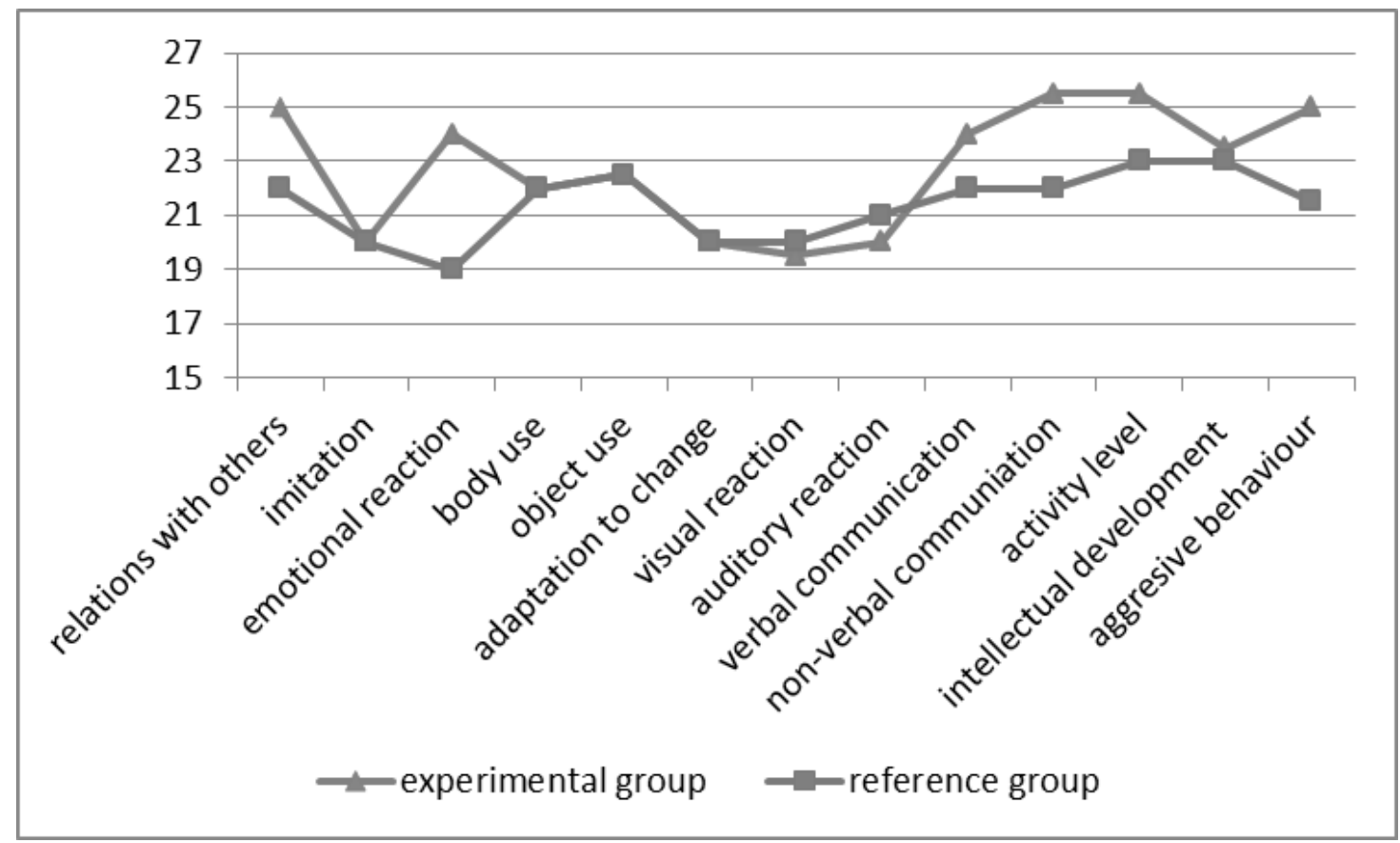

Source: Authors`research.

The next stage of our study consists in conducting of social intervention in a group of ASD children during one year. After that we compared the indices of 
children from the experimental and reference groups. The results of comparison are shown in Fig. 3. As you can see from Fig.3, after the intervention there was established progress in the following indices: relations with others, verbal and nonverbal communication, emotional reactions and activity level. Besides, it is obvious substantial decrease of aggressive behavour of ASD children after the intervention. The results show at effectiveness of correctional practice and necessity of its widening.

Summarizing the above results and our experience of education of ASD children in experimental modeling school, one can formulate the main provisions of their inclusive education.

A primary step is development of integrated educational environment for children with mental retardation and autistic spectrum disorders. Education of children with special educational needs, in particular children with ASD, is to be aimed at their habilitation and integration into society. The child should be assisted in self-identification, self-fulfillment and mastering core knowledge according to curricula and teaching methodological aids, approved by the central executive body, that form and implement national policy of individualized education. Among the most common forms of inclusive education, the following ones are distinguished: educational attainment (complete general secondary education, basic general secondary education, primary education); social rehabilitation (social experience forming, eliminating difficulties of interpersonal relations, activation of basic mental development components) and development correction (organizational forms according to a disorder type, techniques, technical support).

The matter and amount of social services in the course of inclusive education is determined individually for each child with special educational needs depending on his state and requirements. The grounds for providing services are expert advice on variety of meeting specific needs of integrated children and individualized syllabi worked out by a multidisciplinary team. Social services include:

- working out of individualized syllabi by the multidisciplinary team consisting of methodologists in special education, general class teachers, speech therapists, practice psychologists, social teachers, manual labour teachers, physical training teachers, acoustic laboratory instructors, music teachers, an assistant teacher, assistant to a child and parents;

- arrangement of special education keeping to a curriculum of general education but according to the individualized syllabus (amount of working hours, teaching methods and syllabi are determined by the multidisciplinary team taking into account infant development potential and characteristics);

- psychodiagnostics aimed at studying social psychological characteristics of a personality in order to make psychological intervention or psychological rehabilitation and to provide methodological advice;

- creation of required adapted space;

- social studies to acquire social and living skills;

- psychological teaching intervention aimed at forming and recovery of psychological and mental functions and qualities of the child with special edu- 
cational needs, his personality development; providing multidisciplinary team advice on improving relations with social environment;

- involving resources of various institutions, public organizations and persons concerned in order to satisfy educational and specific requirements of the child.

Staffing is an issue of significant importance. It is necessary to introduce professionals (methodologists in special education, remedial teachers, classroom assistants) of new inclusive education disciplines into core teaching training that implies acquiring skills of work with autistic children and improving their professional development at social psychological training sessions and scientific workshops. Psychological and educational support in integrated and inclusive education should be provided by specialists who can be both colleagues and staff school employees. The remedial teacher in his work with autistic children should perform the following duties as:

- carrying out psychological teaching diagnostics of mental autistic children development;

- fixing dynamics of correctional autistic children development;

- development and implementation of individualized psycho-correctional curriculum for teaching, educating and overcoming of autistic disorders;

- making syllabi of individual and frontal classes, compiling diagnostic, stimulating, didactic and corrective material for diagnosing and training;

- approximate forecasting of the infant personality development taking into account dysontogenesis peculiarities;

- implementation of social integrative infant communication with the environment;

- implementing succession of all psychological teaching staff;

- conducting classes with children, advisory assistance to parents, parental co-work, specifying diagnostic indicators as to the obtained correction results;

- development of methodological techniques by educators;

- public consulting aimed at socialization of the child in society.

Upon written request of the parents or persons in loco parentis, the school must provide access to the educational process for the assistant to a child with special educational needs, complying with health legislation requirements should be taken into account. Parents, persons who replace them or the ones with whom parents have entered into an agreement can be the assistants to the child provided they have been trained to act as the assistants. Besides, they are allowed to participate in individual syllabi development, to receive some advice from specialists etc.

In the course of arranging co-education of children with developmental disorders and their healthy peers, considerable attention is focused on work with parents of children with special educational needs and those parents whose children enrolled in the inclusive group. In particular, greatest attention should be paid to tolerant education of the families with neurotypical children. When the child joins the circle of his peers, it favours gradual change in parents' mental state 
that is displayed as stress weakening, emotional state improvement, increase in efficiency of educational and abilitative correctional work. Besides, active, motivated, value-focused and pedagogically guided parental involvement in the educational process leads to decrease in anxiety and fear, raises their efforts to daily and long-term success, shapes quite a new world outlook of the whole family and its familiar surroundings.

In spite of the above analysis the conducted studies have some limits. First of all, the analysis was fulfilled in special education schools for ASD students. Its generalization is not fully consistent with inclusive school. Secondly, teachers of inclusive schools have not enough skill, so they need certification training before inclusion of ASD students. Thirdly, there is not adequate staff in inclusive schools - there are legislative problems, which should be solved before wide inclusion of ASD students in Ukraine. The discussion of the above restrictions demands further investigations.

\section{CONCLUSIONS}

The article is devoted to a study of ASD children peculiarities in Ukraine educational system. In the study 40 students of secondary schools were involved-20 children with ASD and 20 children with mental retardation aged from 8 to 9 years. The following methods were used: Binet-Simon Scale for intelligence level determination; method of neuropsychological research according to Alexander Luria for psychophysical development level determination; and Childhood Autism Rating Scale for autism level determination. The results obtained indicate that children with ASD have lower level of imitation, speech development and concentration of attention than children with mental retardation. The fulfilled analysis confirms the main statement about the necessity of creation of special conditions for ASD children's education. Based on the results obtained a model of autistic children inclusion in educational system of Ukraine was proposed. The model includes structuring of educational space, inclusion in educational process social service directed at ASD children's habilitation and integration into society, current training of staff as well as inclusion of the parents in the educational process.

\section{REFERENCES}

Bobkowich-Lewartowska L. (2000). Autyzm dzieceicy. Zagadnienia diagnozy i terapji [Children autism. Problems of diagnosis and therapy]. Krakow: Impuls.

Bondar, V.I. (2003). Спеціальна педагогіка: Понятійно-термінологічний словник [Specialized pedagogy: The dictionary of terms and notions]. Luhansk: Альма-матер.

Freud, A. (1999). Теория и практика детского психоанализа: ключевые термины [Theory and practice of child psychoanalysis: key terms]. Moscow: Апрель пресс, ЭКСМА-ПРЕСС.

Kolupajeva, А.А. (2007). Управління інклюзивною школою на засадах менеджменту освітніх інновацій / Інклюзивна школа: особливості організації та управління [Inclusive school management based on educational innovation management / Inclusive school: organization and management]. Kyiv: Вища школа.

Kowaluk M. (2009). Efektywnosc terapii pedagogicznej dzieci z trudnosciami w uczeniu sie [Efficacy of peda- 
gogical therapy of children with educational problems]. Lublin: Wydawnictwo Uniwersytetu Marii Curie-Sklodowskiej.

Lebedynska, K.S. \& Nikolska, O.S. (1991). Диагностика раннего детского аутизма [Diagnostics of early childhood autism]. Moscov: Просвещение.

Luria, A.R. (1970). Мозг человека и психологические процессы [Human brain and psychical processes]. Moscov: Просвещение.

Meshcheryakova, B. H., \& Zinchenko, V. P. (2004). Большой психологический словаръ [Great dictionary of psychology]. Moscow: ОЛМА-ПРЕСС.

Ornitz, Е. (2013) Причини дитячого аутизму [Causes of child autism]. Retrieved from http:/ / molodchiy.org.ua/zdorov-ya-ditini/prichini-dityachogo-autizmu.

Ostrovska, K.O. (2012). Peculairties of social competence in children with different autistic level, Journal of Education Culture and Society, 1, p. 133.

Peeters, Т. (2003). Аутизм: Oт теоретического понимания к педагогическому воздействию [Autism: From theoretical understanding to educational intervention]. Moscow: Просвещение.

Pisula E. (2003). Autyzm I przywiazanie [Autism and affection]. Gdansk: Gdanskie Wydawnictwo Psychologiczne.

Schopler, E, \& Reichler, J. (1986). Psychopathology and child development. New York: Plenum Press.

Snezhnevsky, A.V. (1985). Справочник по психиатрии [Psychiatry manual]. Moscow: Медицина.

Shulzhenko, A.Ye., \& Ostrovskii, I.P. (2014). University studies of future psychologist to work with autistic children, Journal of Education Culture and Society, No. 1, P.87.

Shulzhenko, D. I. (2009). Основи психологічної корекції аутистичних порушень у дітей: монографія [Base of psycholocial correction of children with ASD]. Kiev: Національний педагогічний університет імені М.П.Драгоманова.

Skrypnyk, T.V. (2008). Методика дослідження психічних процесів у дошкільників з аутизмом [Method of investigation of psychical process for preschool children with autism]. Kiev: Педагогічна думка. 